called by the villagers, will not suffer the like fate. The Italian Alpine Club, will, we may trust, interest themselves in this matter.

Hotel du Parc, Lugano, October 2I.

P. L. SClater.

Who discovered the Teeth in Ornithorhynchus?

As Dr. Hart Merriam's letter on the above subject in your issue of the 7 th inst. (p. II) will be read by many who have not access to Sir Everard Home's "Lectures on Comparative Anatomy, "allow me to point out that the description and figures in that work referred to by Dr. Merriam have no bearing whatever upon the very interesting discoveries recently made. They represent, not the real teeth of the young animal discovered by Mr. Poulton, and fully described by Mr. Oldfield Thomas, but the well-known horny plates which functionally take their place in the adult, and which are called "grinding teeth" by Sir Everard only in a very general sense. W. H. FLOWER.

British Museum (Natural History), November 9.

THE account of the teeth of Ornithorhynchus, given by S:r Everard Home in "Lectures on Comparative Anatomy," vol. i. p. 305, explanatory of Tab. lix. vol. ii., referred to by Mr. Hart Merriam in your last issue ( $\mathrm{p}$. II), shows, even more clearly than the figures, that the true teeth had not been noticed at that time (1814). The passage is as follows:- "In the posterior portion of the mouth, both in the upper and lower jaw, are placed grinding teeth with broad flattened crowns, four in number, one on each side of each jaw. They are composed of a horny substance (the italics are my own), only embedded in the gum, to which they are connected by an irregular surface in the place of fangs. When cut through, the substance appears fibrous, like that of nail ; the direction of the fibres being perpendicular to the crown, similar to that of the horny crust of the gizzard. The teeth in the young animal are smaller, and two on each side, so that the first teeth are probably shed, and the two small ones replaced by one large one."

It is perfectly evident that here no reference is made to the true teeth, and, moreover, the figure of the two smaller " teeth" of young specimens represents merely the immature horny plates. The honours, therefore, still remain with Mr. Poulton and Mr. Oldfield Thomas.

Anatomical Department, The Museum, Oxford, November 8.

On a Mite of the Genus Tetranychus found infesting Lime-trees in the Leicester Museum Grounds.

ABouT the $3^{\text {th }}$ of last September my attention was called to the strange appearance of a row of lime-trees standing in front of the School of Art buildings in Hastings Street. On examination I found that the whole row, with, I think, only one exception, were almost entirely devoid of leaves, the trunks and branches being covered with a fine web, very closely spun, giving them the appearance of being coated with a thin layer of ice, this glazed look being specially noticeable when standing in such a position as to catch the reflected rays of the sun. At first sight I imagined that I was examining the work of a spider, though I was unable to recollect any whose webs would accord with the character of those under observation. However, a close inspection revealed the webs to be tenanted by an in numerable number of yellowish or orange-coloured mites which were in some places associated together in dense masses or clusters, and more or less abundant over the whole of the trunks and branches.

These mites appeared, on being subjected to a careful microscopical examination, to be identical with Tetranychus tiliarum, Mull, a species which it seems that Claparède considers to be onily a variety of $T$. telarizus, the common "red spider." However that may be, they are at any rate closely allied forms-members of the family Tromóidiida, which possess, as one of their distinguishing characteristics, a pedipalpus with a claw and a lobe-like appendage. In the genus Tetranychus the palpi are chelate, the mouth is furnished with a barbed sucking apparatus for the extraction of plant juices, and spinning organs are usually present. It is needless to comment upon their destructiveness to vegetation, for most keepers of gardens and hothouses are familiar with their ravages in one direction or another, and the difficulty experienced in thoroughly extirpating them.

In connection with the species which forms the subject of the present communication, I notice that Murray, in his work on the "Aptera," says: "It occasionally occurs in such numbers as almost to denude the trees of their foliage; and it has been noted that the stems and branches of such trees seemed covered with a bright glaze. Can this be a fine web?" It was so, most certainly, in the present instance, which afforded me a most favourable opportunity for examination. Again, it appears that the mites are normally found on the under-surface of the leaves, which they cover with a fine web of silk, on which (to again quote Murray) "they are sometimes crowded together in vast numbers ; for example, we have seen them so thick on the leaves that they looked as if they were not merely sprinkled with a yellow orange-coloured powder, but as if it was actually in parts heaped up on them, so that none of the green colour of the leaf was visible." Their presence is of course highly injurious, causing the leaves to shrivel and drop; and it seems to me that the fact of their occurrence on the bare bark of the trunks was attributable to the death of the leaves causing them to retreat to that position, uncongenial though it would seem to be. Such trees as preserved their foliage presented no abnormal appearance on the branches, \&c., notwithstanding which, in one or two instances, I believe the parasites were present on the leaves, though seemingly not in such extraordinary profusion.

Dugès, writing of $T$. telarizus, states his belief that that species passes the winter under stones, and instances the finding of several active individuals so situated in a garden near Paris in the month of October. Regarding this point I may say that my specimens of $T$ : tiliarum, which I placed in a box immediately after removal from the trees, speedily ensconced themselves in the most convenient nooks and crannies, in which they spun fine webs. It may be worth noting that the days on which my observations were made were warm and damp, with scarcely any wind, quite typical early autumn days in fact.

Leicester Museum.

F. R. ROWLEY.

\section{Retarded Germination.}

I SHALt be much obliged to any of your readers who can give an explanation of the probable cause of the above phenomenon, which I have remarked this year. I sowed a number of patches of seeds of various hardy annuals in the garden in the last week of April ; about half of then came up after the usual interval, strongly and regularly. Such were Calendula Pongei, Convolvulus minor, Lavatera trimestris, Collinsia bicolor, Iberis white and red, Specularia specuium, Linum mubrum, \&c., \&c. Then there were some of which a few scattered seedlings made their appearance at this time, and after an interval of about six weeks the greater part of them also came up; among these were Eutoca viscida, Nigelia damascena, Sphenosyne, and Clarkia pulchella. Thirdly, there were some of which I quite despaired ; mignonette, however, appeared thinly about the end of June, and at intervals till August; and in the middle of June a few plants (in proportion to the seed sown, a few) of Linaria bipartita, Madia elegans, and Xeranthemum came up-one consequence being that the last named has not yet flowered. Some of the seeds were obtained this spring from seedsmen, some were my own collection of the last year or two-of the latter were Calendula, Lavatera, Convolvulus, Specularia, Eutoca, Nigella, Sphenogyne, and mignonette-so that cannot be said to give any clue. The conditions for germination and growth were favourable, and the season also. I have never remarked before any anmuals so long in appearing above ground; though in some herbaceous plants I have noticed it, e.g. Gaillardia, Myosotis alpestris, and Anemone coronaria.

Herefordshire, September 19.

\section{The Relation of the Soil to Tropical Diseases.}

As a humble subscriber to and student of NATURE, will yon bear with me while I ask your help, as shortly and plainly as I can? I am in a very secluded corner of one of the Native States of Rajpootana, and I am collecting facts and making observations on the relation of the soil to tropical diseases; my ambition being to discuss it not so much from a statistical and geographical standpoint, as from the geological, in its chemical and biological 